\title{
Loss of miR-200c up-regulates CYP1B1 and confers docetaxel resistance in renal cell carcinoma
}

\author{
Inik Chang ${ }^{1,2, *}$, Yozo Mitsui ${ }^{1,3, *}$, Shinichiro Fukuhara ${ }^{1,3}$, Ankurpreet Gill ${ }^{1}$, Darryn K. \\ Wong ${ }^{1}$, Soichiro Yamamura ${ }^{1,3}$, Varahram Shahryari ${ }^{1}$, Z. Laura Tabatabai ${ }^{4}$, Rajvir \\ Dahiya $^{1,3}$, Dong Min Shin ${ }^{2}$ and Yuichiro Tanaka ${ }^{1,3}$ \\ ${ }^{1}$ Department of Surgery and Division of Urology, Veterans Affairs Medical Center, San Francisco, California, United States \\ of America \\ 2 Department of Oral Biology, Yonsei University College of Dentistry, Seoul, South Korea \\ 3 Department of Urology, University of California, San Francisco, California, United States of America \\ ${ }^{4}$ Department of Pathology, Veterans Affairs Medical Center and University of California, San Francisco, California, United \\ States of America \\ * These authors are equally contributed to this work \\ Correspondence to: Inik Chang, email: ichang@yuhs.ac
}

Yuichiro Tanaka, email: yuichiro.tanaka@ucsf.edu

Keywords: Renal cell carcinoma, CYP1B1, miR-200c, chemotherapy, docetaxel

Received: November 19,2014 Accepted: February 04, $2015 \quad$ Published: March 08, 2015

This is an open-access article distributed under the terms of the Creative Commons Attribution License, which permits unrestricted use, distribution, and reproduction in any medium, provided the original author and source are credited.

\section{ABSTRACT}

Despite high protein expression and enzymatic activity of cytochrome P450 1B1 (CYP1B1) in renal cell cancer (RCC), its functional significance has not been elucidated. Here we explored the functional role and regulatory mechanism of CYP1B1 in RCC. Reduction of CYP1B1 levels fail to prevent in vitro tumorigenicity such as proliferation, apoptosis, and cell cycle progression of RCC cells. Moreover, the expression levels are not associated with tumor type, stage, Fuhrman grade and 5-year survival probability after surgery. Instead, alteration of CYP1B1 expression regulates the chemosensitivity of RCC cells to docetaxel suggesting its critical contribution to the chemoresistance. Additionally, miR-200c, which is significantly down-regulated in RCC regulates CYP1B1 expression and activity. An inverse association was also observed between the expression levels of miR-200c and CYP1B1 protein in RCC tissues. Finally, alteration of miR-200c levels affects the chemosensitivity of RCC cells. Restoration of docetaxel resistance by exogenous expression of CYP1B1 in miR-200c-over-expressing cells indicates that CYP1B1 is a functional target of miR-200c. These results suggest that CYP1B1 up-regulation mediated by low miR-200c is one of the mechanisms underlying resistance of RCC cells to docetaxel. Therefore, expression of CYP1B1 and miR-200c in RCC may be useful as a prediction for docetaxel response.

\section{INTRODUCTION}

Renal cell cancer (RCC) accounts for $2-3 \%$ of all tumor malignancies in human. In 2008, an estimated 54,000 adults in the United States was diagnosed with RCC and approximately one third of newly diagnosed patients present with metastases [1]. The 5-year survival rate for patients with metastatic RCC is less than $10 \%$ probably due to its low response to chemo- and radiotherapy [2].
Cytochrome P450 (CYP) is a multi-gene family of enzymes implicated in the metabolism of a diverse range of xenobiotics and endogenous compounds. Cytochrome P450 1B1 (CYP1B1) belongs to the CYP1 family and is the only member of the CYP1B subfamily. It is involved in the hydroxylation of estrogen and activation of environmental carcinogens [3]. CYP1B1 expression can be induced by polycyclic aromatic hydrocarbons such as 2, 3, 7, 8-tetrachlorodibenzo- $p$-dioxin and is also regulated by peptide hormones, cAMP, aryl hydrocarbon receptor and estrogen receptor $[4,5]$. CYP1B1 protein 
is found in cancer cells but is undetectable in the normal cells of cancerous and normal tissues [6]. In contrast, there is no obvious difference in CYP1B1 mRNA levels between cancer and normal tissues, suggesting that its expression is regulated at the post-transcriptional level. Indeed, proteasome- and microRNA (miRNA)-mediated CYP1B1 regulation have been suggested to explain the discrepancy $[7,8]$. The tumorigenic effects of CYP1B1 are believed to be its ability to produce 4-hydroxy estrogens via hydroxylation of the parent estrogen [9]. 4-Hydroxyestrogen undergoes further metabolic conversion to other reactive compounds such as estradiol-3, 4-quinone and semi-quinones. It has been postulated that DNA damage, mutation, and depurination caused by the metabolites of CYP1B1 activation initiate carcinogenesis [10]. In addition, CYP1B1 up-regulation is also thought to contribute to the chemoresistant phenotype of cancers. CYP1B1 overexpression decreased sensitivity to docetaxel in vitro [11] and its polymorphic allele leading both increased expression and activity is associated with poor response to taxanes in breast and prostate cancers [12, 13]. Due to these characteristics, CYP1B1 has been recognized as a potential tumor biomarker and a promising target for anticancer therapy. In fact, it has been demonstrated that CYP1B1 inhibition prevents endometrial and head and neck carcinogenesis $[14,15]$. However, despite its potential tumorigenic effects, little is known about the functional significance of CYP1B1 in RCC.

MiRNAs are small noncoding RNAs of approximately 20-23 nucleotides that function in posttranscriptional gene regulatory pathways via targeting the 3'-untranslated region (UTR) of mRNAs [16]. Numerous studies have demonstrated that miRNAs have fundamental roles in many key cellular processes, such as proliferation, differentiation and apoptosis, and its altered expression has been described in many human cancers [17]. The miR-200 family containing miR-200a, $-200 \mathrm{~b}$, $-200 c,-141$ and -429 has been shown to play an important role in epithelial to mesenchymal transition (EMT) by repressing zinc finger E-box binding homeobox proteins 1 and 2, and inducing E-cadherin expression [18]. Loss of miR-200 family members occurs in many different human cancers and miR-200c is down-regulated in RCC [19-21]. In addition to its role in EMT, miR-200c has been shown to regulate drug resistance of various types of cancers such as bladder [22], non-small cell lung [23], esophageal [24], breast [25], and ovarian [26] cancers. Although low response to chemotherapeutics is a distinctive characteristic of RCC, it is not known whether miR-200c is involved in RCC chemoresistance.

In this study, we show that CYP1B1 up-regulation, which is associated with the reduced miR-200c expression, is involved in the chemosensitivity of RCC cells to docetaxel.

\section{RESULTS}

\section{Functional role of CYP1B1 in RCC cells}

To determine the functional significance of CYP1B1 in $\mathrm{RCC}$, we examined whether reduction of CYP1B1 levels affects in vitro tumorigenicity. Transfection with two different CYP1B1 siRNAs resulted in a dramatic reduction in endogenous levels of CYP1B1 mRNA in A498 cells (Supplementary Fig. S1A). However, CYP1B1 knockdown did not affect cell proliferation, apoptosis and cell cycle regulation (Supplementary Fig. S1B-D). Since the association of CYP1B1 with the docetaxel response has been studied both in vitro and in vivo [11-13], we examined the potential function of CYP1B1 in docetaxel resistance of RCC cells. According to the cytotoxic activity of docetaxel in several RCC cell lines, the resistance was found to be dependent on the cell line. Thus, A498 and Caki-2 cells exhibited high levels of resistance with $\mathrm{IC}_{50}$ values of 74.6 and $66.8 \mu \mathrm{M}$, respectively, whereas ACHN and 786-O cells were significantly sensitive to docetaxel with $\mathrm{IC}_{50}$ values of 1.55 and $1.3 \mu \mathrm{M}$, respectively. Caki1 and 769-P cells showed a middle range of $\mathrm{IC}_{50}$ values of 11.0 and $24.0 \mu \mathrm{M}$, respectively (Fig. 1A). Next, we examined whether CYP1B1 expression is associated with the chemosensitivity to docetaxel. As shown in Fig. 1B and C, CYP1B1 protein levels in A498 and Caki-2 cells which present a resistant phenotype were relatively higher than that of ACHN and 786-O cells which were sensitive to docetaxel. In addition, after docetaxel treatment, ACHN and 786-O cells expressing relatively low levels of CYP1B1 protein exhibit reduced survival rate and less colony-forming ability than A498 and Caki-2 cells expressing relatively high levels of CYP1B1 protein (Fig. 1D and E). Flow cytometry analysis revealed a more significant increase in cell death of ACHN and 786-O cells than A498 and Caki-2 cells (Fig. 1F). Since taxane-induced cytotoxicity is controlled by CYP2C8 [27], CYP3A4 [28], and ABCB1 [29], we examined their protein expression in RCC cells. However, expression of these proteins was not correlated with the sensitivity to taxanes (data not shown). These results suggest that CYP1B1 may be involved in the regulation of RCC cell response to docetaxel.

\section{CYP1B1 regulates RCC cell resistance docetaxel}

To determine whether the regulation of CYP1B1 levels affects chemosensitivity to docetaxel, we performed knockdown experiments using CYP1B1 specific siRNA in A498 cells, which express relatively high levels of endogenous CYP1B1 protein. Transfection with two different CYP1B1 siRNAs results in a dramatic reduction in endogenous levels of CYP1B1 mRNA (Supplementary 
Fig. S1A), protein (Fig. 2A) and enzyme activity (Fig. 2B). CYP1B1 knockdown significantly increased the cytotoxic effect of docetaxel (Fig. 2C) and decreased the survival rate of A498 cells (Fig. 2D). In reciprocal experiments, we examined whether CYP1B1 over-expression increased the chemoresistance of RCC cells to docetaxel. Transient transfection of a plasmid containing human CYP1B1 into 786-O cells, which express relatively low levels of endogenous CYP1B1 protein resulted in a significant increase in protein level (Fig. 2E) and enzyme activity compared to transfection of control vector (Fig. 2F). Over-expression of CYP1B1 reduced the cytotoxic effect of docetaxel (Fig. 2G) and as a consequence, the survival of 786-O cells was also enhanced (Fig. 2H). Collectively, these results indicate that CYP1B1 plays an important role in the response of RCC cells to docetaxel.

\section{Clinicopathologic analysis of CYP1B1 expression in RCC tissues}

Despite high protein expression and elevated enzymatic activity of CYP1B1 in RCC $[6,30]$, the association of CYP1B1 with RCC development and clinicopathologic relevance is unknown. To determine whether the CYP1B1 protein expression levels are related with the clinicopathologic features and risk of RCC progression, we analyzed 59 patient samples who underwent nephrectomy for RCC, 24 of whom also had adjacent normal kidney samples available for analysis by immunohistochemistry. While the CYP1B1 level was weak or not detected in most of the normal tissues, majority of RCC tissue samples showed moderate or strong CYP1B1 immunoreactivity with average staining scores of $2.10 \pm 0.11$ (versus $0.60 \pm 0.20$ in normal tissues) (Fig. 3A and B). Unlike protein expression, no significant difference was observed in the levels of CYP1B1 mRNA in both RCC tissues and cell lines (Supplementary Fig. S2). According to the scoring, we categorized the RCC samples into weak (28.8\%), moderate (32.2\%) and strong $(39.0 \%)$ staining groups (Fig. 3C). As shown in Fig. 3D, no correlation was observed between CYP1B1 levels and 5 -year survival probability after surgery $(P=0.8485)$. Of the RCC tissue samples, 49 of $59(83 \%)$ were clear cell and 7 of $59(11.9 \%)$ were papillary subtypes. In addition, 3 of $59(5.1 \%)$ tumors were identified as granular, tubular carcinoma, or oncocytoma (Table 1). We further assessed whether CYP1B1 expression in clinical samples are correlated with clinicopathologic characteristics such as tumor types, stage and Fuhrman grade. However, no statistically significant correlation was observed between
A

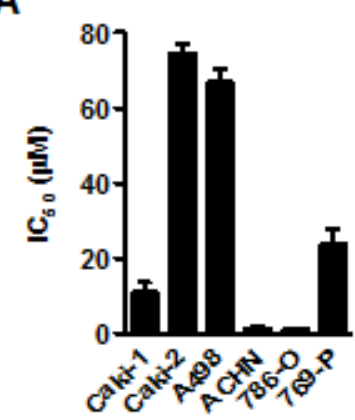

D

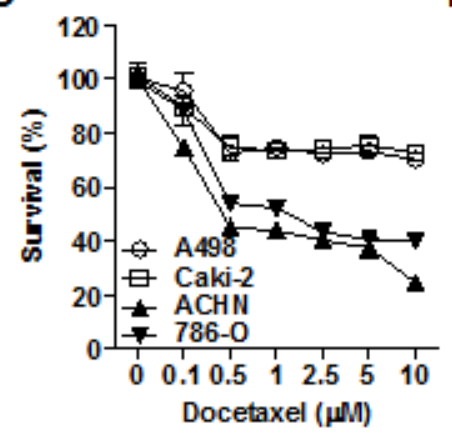

B

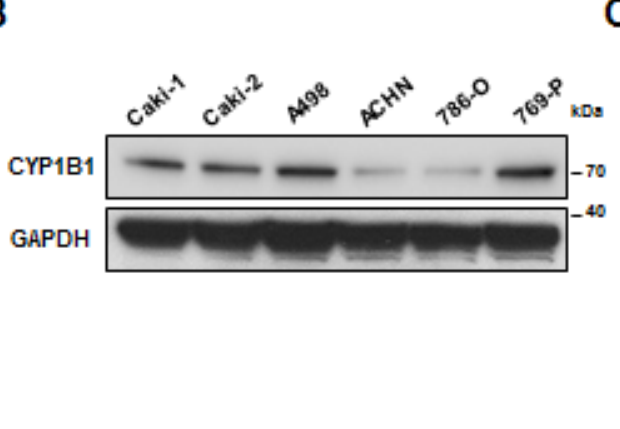

C

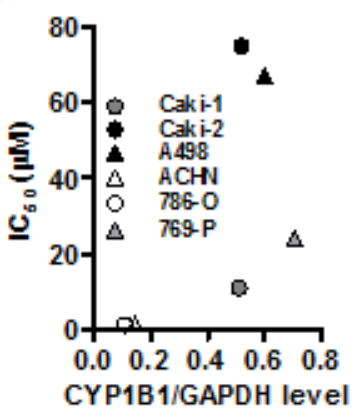

E

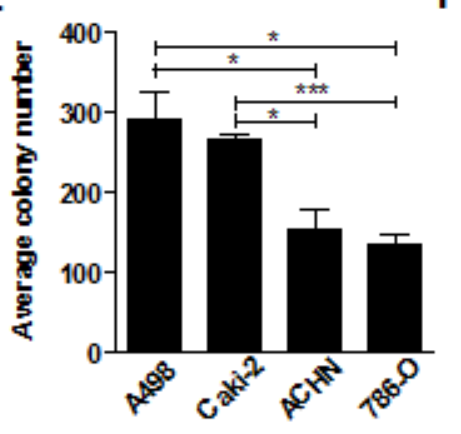

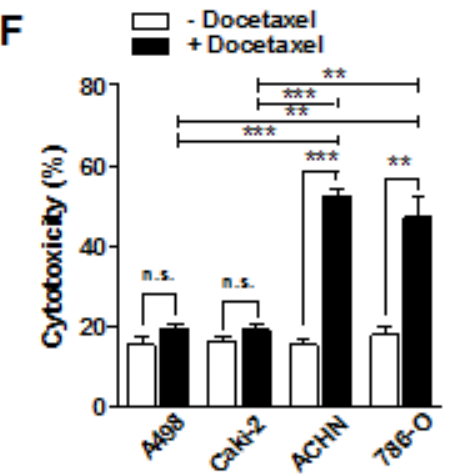

Figure 1: CYP1B1 expression is involved in the docetaxel resistance of RCC cells. (A) Chemosensitivity assay was conducted at $72 \mathrm{~h}$ after docetaxel treatment. Values indicate mean $\mathrm{IC}_{50} \pm \mathrm{SEM}$. (B) CYP1B1 protein expression in RCC cells was determined by Western blot. (C) The correlation of CYP1B1 protein expression with $\mathrm{IC}_{50}$. CYP1B1 protein level normalized by GAPDH expression was plotted against $\mathrm{IC}_{50}$ of different RCC cells. (D) Dose-dependent response of RCC cells was examined at $72 \mathrm{~h}$ after indicated concentration of docetaxel treatment. (E) Colony formation assay was performed at 14 days after docetaxel $(5 \mu \mathrm{M})$ treatment. $* P<0.05 ; * * * P<0.001(\mathrm{~F})$ Cytotoxicity was measured with annexin V-FITC/7-AAD staining at $72 \mathrm{~h}$ after docetaxel $(5 \mu \mathrm{M})$ treatment. $* P<0.05 ; * * P<0.01$ 
A

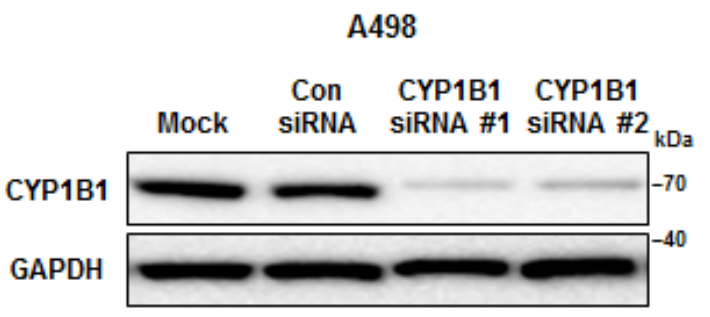

C

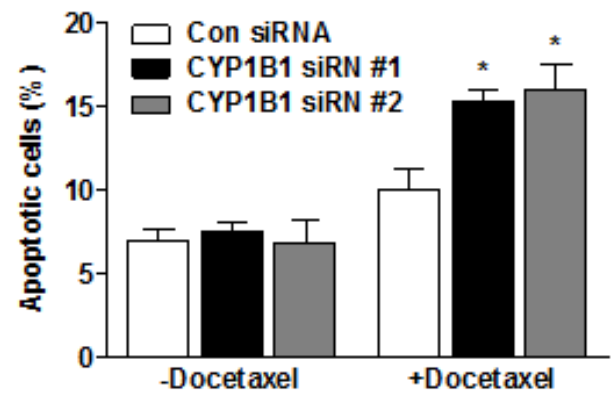

E

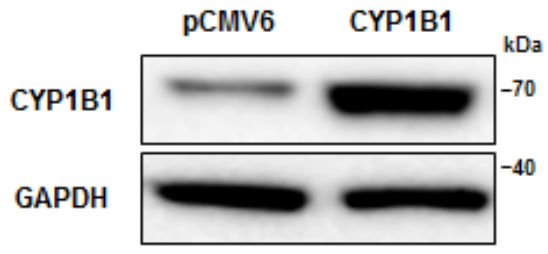

G

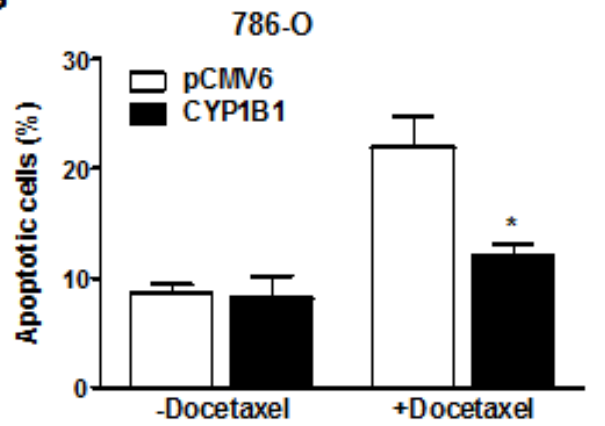

B

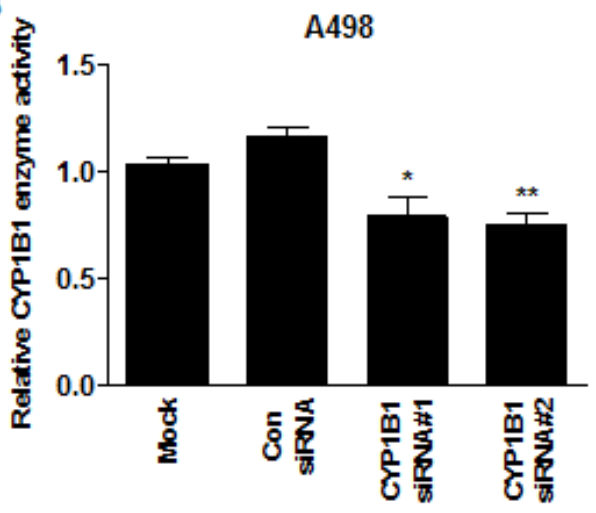

D

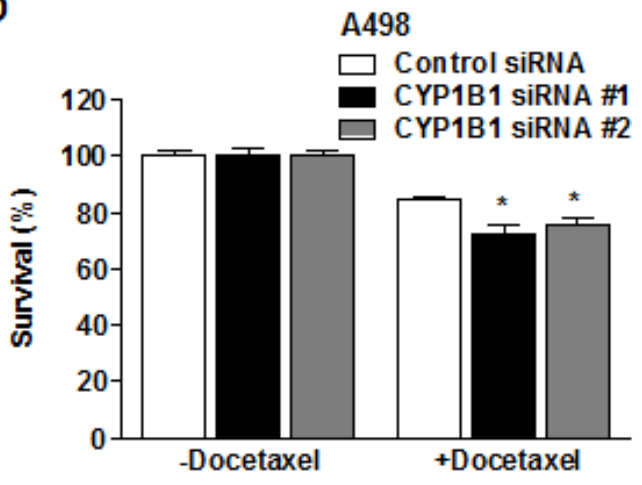

$\mathbf{F}$

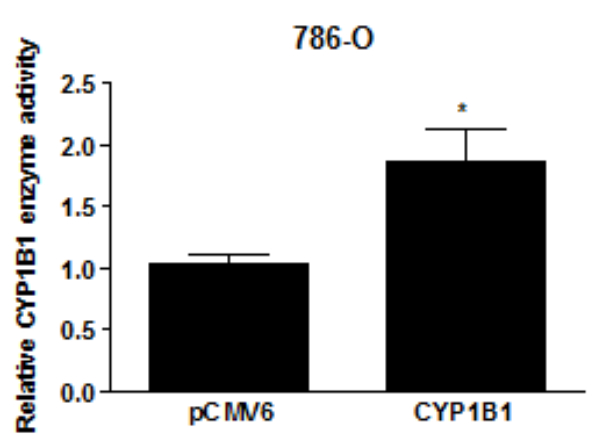

$\mathrm{H}$

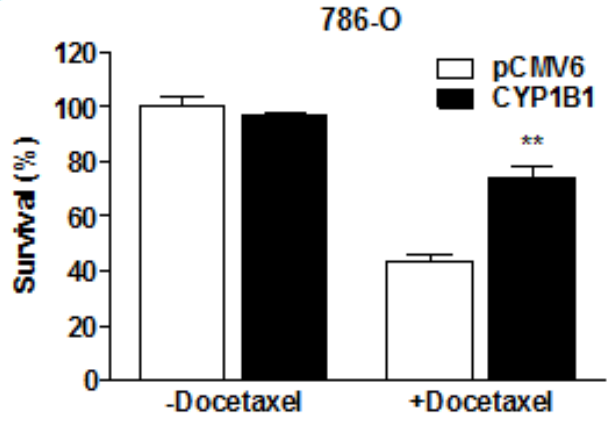

Figure 2: Change in CYP1B1 expression alters docetaxel resistance of RCC cells. (A and B) After siRNA transfection, CYP1B1 protein expression was determined by Western blot (A) and enzyme activity was measured with P450-Glo assay (B) in A498 cells. ${ }^{*} P<0.05 ; * * P<0.01$ (C and D) After CYP1B1 siRNA transfection, A498 cells were treated with docetaxel $(5 \mu \mathrm{M})$ for 72 hrs. Apoptotic cell death was measured with annexin V-FITC/7-AAD staining (C) and cell survival was analyzed by MTS assay (D). * $P<0.05$ (E and F) After plasmid transfection, CYP1B1 protein expression was determined by Western blot (E) and enzyme activity was measured with P450Glo assay (F) in 786-O cells. ${ }^{*} P<0.05(\mathrm{G}$ and H) After CYP1B1 plasmid transfection, 786-O cells were treated with docetaxel $(5 \mu \mathrm{M})$ for 72 hrs. Apoptotic cell death was measured with annexin V-FITC/7-AAD staining $(\mathrm{G})$ and cell survival was analyzed by MTS assay $(\mathrm{H})$. $* P<0.05 ; * * P<0.01$ 
Table 1: Association of CYP1B1 expression with the clinicopathologic characteristics of RCC

\begin{tabular}{|c|c|c|c|c|c|}
\hline \multirow{2}{*}{$\begin{array}{l}\text { Pathological } \\
\text { variables }\end{array}$} & \multirow{2}{*}{$\begin{array}{c}\text { Total } \\
(n=59) \\
n(\%)\end{array}$} & \multicolumn{3}{|c|}{ CYP1B1 expression } & \multirow[b]{2}{*}{$P$} \\
\hline & & $\begin{array}{l}\text { Weak } \\
(n=17)\end{array}$ & $\begin{array}{l}\text { Moderate } \\
(n=19)\end{array}$ & $\begin{array}{l}\text { Strong } \\
(n=23)\end{array}$ & \\
\hline \multicolumn{6}{|l|}{ Age } \\
\hline Mean \pm SD, years & $66.2 \pm 6.8$ & - & - & - & \\
\hline \multicolumn{6}{|l|}{ Sex } \\
\hline Men & $37 / 59(62.7)$ & $12 / 37(45.9)$ & $10 / 37(27.0)$ & $15 / 37(40.5)$ & \multirow{2}{*}{0.5201} \\
\hline Women & $22 / 59(37.2)$ & $5 / 22(22.7)$ & 9/22 (40.9) & $8 / 22(36.4)$ & \\
\hline \multicolumn{6}{|l|}{ Histological type } \\
\hline Clear cell & 49/59 (83.0) & $13 / 49(26.5)$ & $17 / 49(34.7)$ & $19 / 49(38.8)$ & \multirow{5}{*}{0.5204} \\
\hline Papillary & $7 / 59(11.9)$ & $2 / 7(28.6)$ & $1 / 7(14.3)$ & $4 / 7(57.1)$ & \\
\hline Granular & $1 / 59(1.7)$ & - & $1 / 1(100)$ & - & \\
\hline Tubular & $1 / 59(1.7)$ & $1 / 1(100)$ & - & - & \\
\hline Oncocytoma & $1 / 59(1.7)$ & $1 / 1(100)$ & - & - & \\
\hline \multicolumn{6}{|l|}{ Tumor stage } \\
\hline pT1 & $31 / 59(52.5)$ & 9/31 (29.0) & $7 / 31(22.6)$ & $11 / 31(35.5)$ & \multirow{4}{*}{0.0977} \\
\hline $\mathrm{pT} 2$ & $11 / 59(18.6)$ & $2 / 11(18.2)$ & $4 / 31(12.9)$ & $9(81.8)$ & \\
\hline pT3 & $13 / 59(22.0)$ & $6 / 13(46.2)$ & $6 / 13(46.2)$ & $1 / 13(7.7)$ & \\
\hline pT4 & $4 / 59(6.8)$ & - & $2 / 4(50.0)$ & $2 / 4(50.0)$ & \\
\hline \multicolumn{6}{|l|}{ Nuclear grade } \\
\hline 1 & $35 / 59(59.3)$ & $14 / 35(40.0)$ & $12 / 35(34.3)$ & 9/35 (25.7) & \multirow{4}{*}{0.1656} \\
\hline 2 & $14 / 59(23.7)$ & 2/14 (14.3) & $3 / 14(21.4)$ & $9 / 14(64.2)$ & \\
\hline 3 & $6 / 59(10.2)$ & $1 / 6(16.7)$ & 2/6 (33.3) & $3 / 6(50.0)$ & \\
\hline 4 & $4 / 59(8.5)$ & - & $2 / 4(50.0)$ & $2 / 4(50.0)$ & \\
\hline \multicolumn{6}{|l|}{ Vascular invasion } \\
\hline Negative & $56 / 59$ (94.9) & - & - & - & \\
\hline Positive & $3 / 59(5.1)$ & - & - & - & \\
\hline \multicolumn{6}{|l|}{ Capsular invasion } \\
\hline Negative & $57 / 59(96.6)$ & - & - & - & \\
\hline Positive & $2 / 59(3.4)$ & - & - & - & \\
\hline
\end{tabular}

CYP1B1 expression and these pathological parameters. A comprehensive summary of the CYP1B1 staining patterns and its association with several clinicopathologic variables is shown in Table 1.
CYP1B1 level is inversely correlated with miR200c expression in RCC

Since CYP1B1 overexpression causes resistance of RCC cells to docetaxel, we looked of the regulatory mechanisms of CYP1B1 expression with a focus on miRNAs. We searched for potential candidate miRNAs, which have been reported to be altered in RCC. According to miRNA expression profiling studies, miR-200c is 
significantly down-regulated in RCC [19, 20]. Therefore, we analyzed miR-200c expression in microdissected human renal cancer tissues and matched adjacent normal regions, which were used for the CYP1B1 expression study $(n=24)$. While the expression of miR-200c was unaltered in 4 samples or up-regulated in 3 of the 24 cases, most of RCC tissues (17 of 24 cases) had low miR-200c levels relative to the matched normal samples (Fig. 4A and B). We verified these results by in situ hybridization analysis and again observed attenuated miR-200c expression (Fig. 4C). Patient and tumor characteristics used in these studies are summarized in Supplementary Table S1.

To determine whether miR-200c expression is associated with CYP1B1 level, we investigated the relationship between the levels of CYP1B1 protein and miR-200c in human RCC tissues (Fig. 4D). RCC tumors with strong CYP1B1 expression showed low miR200 c levels $(1.87 \pm 0.36$ versus $5.14 \pm 0.58$ in tumor samples with weak CYP1B1 expression). In addition, a significant difference was also observed between

RCC tumors with moderate and low CYP1B1 levels (3.36 \pm 0.50 versus $5.14 \pm 0.58$ in tumor samples with weak CYP1B1 expression). Thus, an inverse association was found between miR-200c expression and CYP1B1 protein levels in human RCC tissues. In addition to the majority of RCC cell lines showed low expression of miR200c compared with HK-2 cells but 786-O cells, which express low CYP1B1 levels exhibited high miR-200c expression (Fig. 4E). In contrast to the CYP1B1 protein level, no relationship was found between CYP1B1 mRNA and miR-200c expression in the human RCC tissues (Supplementary Fig. S3). These results suggest that low expression of miR-200c results in high levels of CYP1B1 protein in RCC tumors.

\section{CYP1B1 is a direct target of miR-200c}

In silico analysis (http://www.microrna.org/ and http://targetscan.org/) showed that CYP1B1 3'-UTR contains two potential complementary miR-200c binding sequences which are termed miR-200c complementary

A

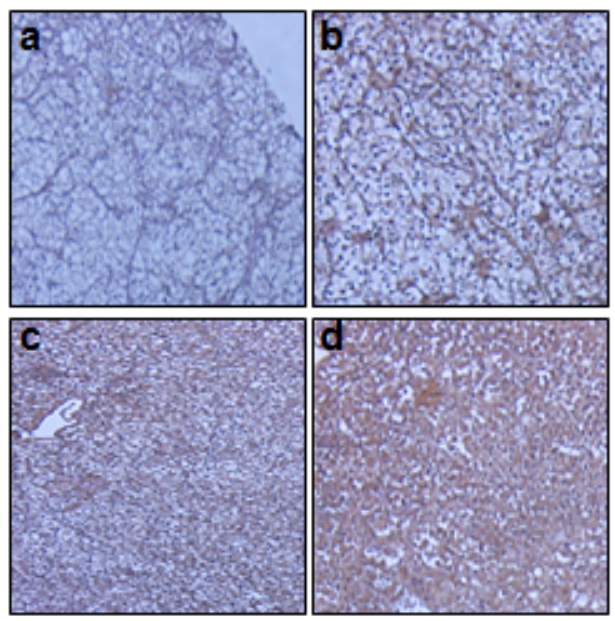

C

\begin{tabular}{|c|c|}
\hline $\begin{array}{c}\text { CYP1B1 expression } \\
\text { level }\end{array}$ & $\begin{array}{c}\text { Total } \\
(\mathbf{n}=59) \\
\mathbf{n}(\%)\end{array}$ \\
\hline Weak & $17(28.8)$ \\
\hline Moderate & $19(32.2)$ \\
\hline Strong & $23(39.0)$ \\
\hline
\end{tabular}

B

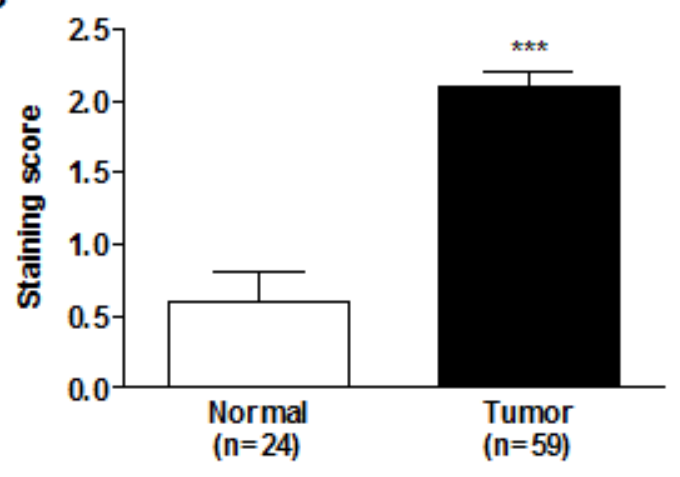

D

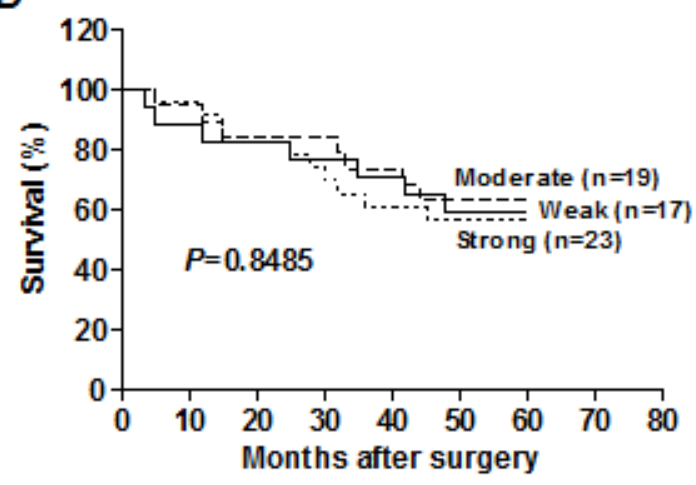

Figure 3: CYP1B1 protein is up-regulated in RCC tissues. (A) Immunohistochemical staining of CYP1B1 protein expression in RCC patients tissues. (a-d) Representative images showing immunoreactive CYP1B1 in normal (a) and RCC (b-d) tissues (magnification: $\times 400$ ). (B) Summary of CYP1B1 immunostaining score. Staining intensity was assessed as described in Materials and Methods. ${ }^{* * *} P<0.001$ (C) Summary of CYP1B1 expression levels in RCC tissue samples. (D) Kaplan-Meier analysis for the correlation of CYP1B1 expression with 5 year survival after surgery in RCC patients. 
sequence 1 and 2, respectively (MCS1 and MCS2) (Fig. 5A). To examine whether CYP1B1 expression is regulated by miR-200c, we cloned various 3'UTR reporter constructs containing the MCSs or controls (Fig. 5B) and conducted luciferase assays with 786-O and A498 cells, respectively. With 786-O cells, the luciferase activity of the construct containing two copies (pMir-1B1/MCS1MCS2) or one copy (pMir-1B1/MCS1 or pMir-1B1MCS2) of MCS was significantly lower than that of the control plasmid. However, the luciferase activity of the construct containing no MCS (pMir-1B1/DMCS1- $\triangle \mathrm{MCS} 2)$ showed no change compared to the control vector. In A498 cells, only the luciferase activity of pMir1B1/MCS1-MCS2 was significantly decreased probably due to the low endogenous miR-200c expression. To investigate the direct regulation of CYP1B1 expression by miR-200c, luciferase activities were measured after miR-200c inhibition or overexpression. As shown in Fig. 5D, inhibition of endogenous miR-200c increased the luciferase activities of the pMir-1B1/MCS1-MCS2 but not that of pMir-1B1/ $\mathrm{MCS} 1-\triangle \mathrm{MCS} 2$. In reciprocal experiments, exogenous miR-200c expression decreased

A

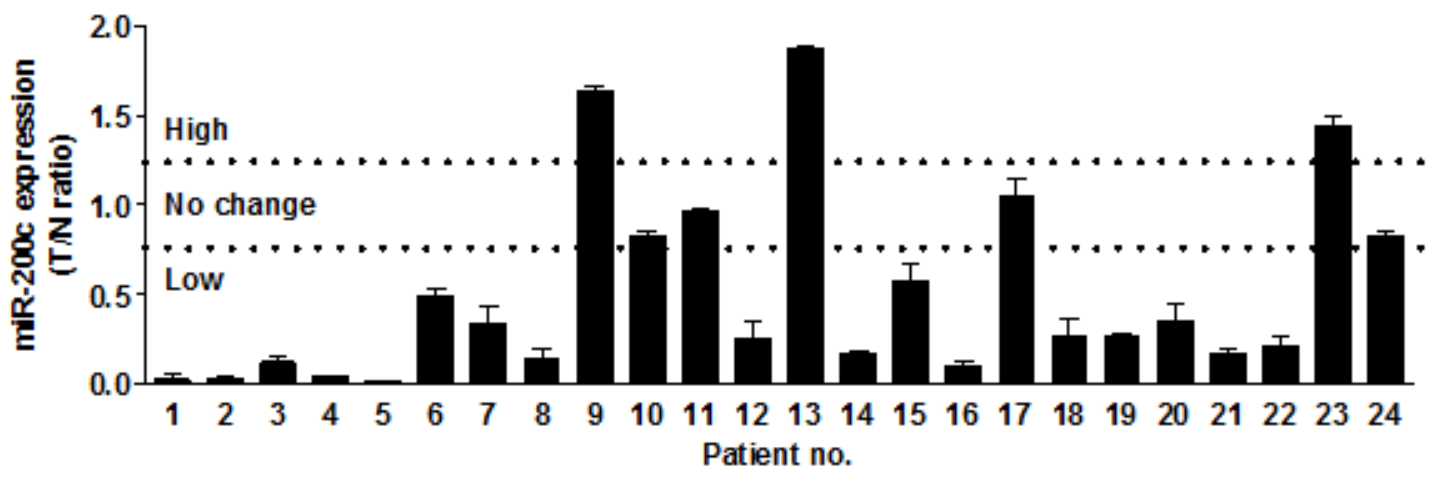

B

C

\begin{tabular}{|c|c|c|}
\hline $\begin{array}{c}\text { miR-200c expression } \\
\text { (T/N ratio) }\end{array}$ & $\begin{array}{c}\text { Total }(\mathrm{n}=24) \\
\mathrm{n}(\%)\end{array}$ & $P$ \\
\cline { 1 - 2 } Low $(<0.75)$ & $17 / 24(70.8)$ & \multirow{2}{*}{0.0164} \\
\cline { 1 - 2 } No change (0.75-1.25) & $4 / 24(16.7)$ & \\
\cline { 1 - 2 } High (>1.25) & $3 / 24(12.5)$ & \\
\hline
\end{tabular}

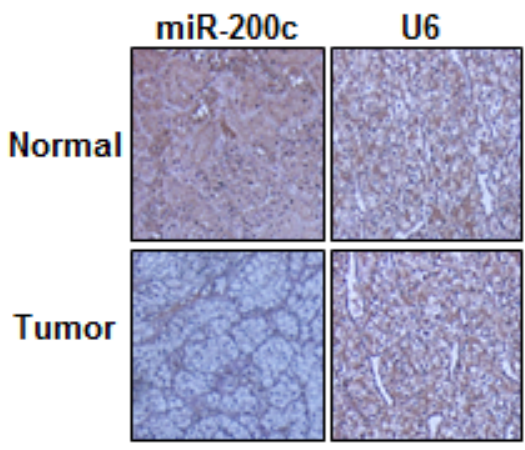

D

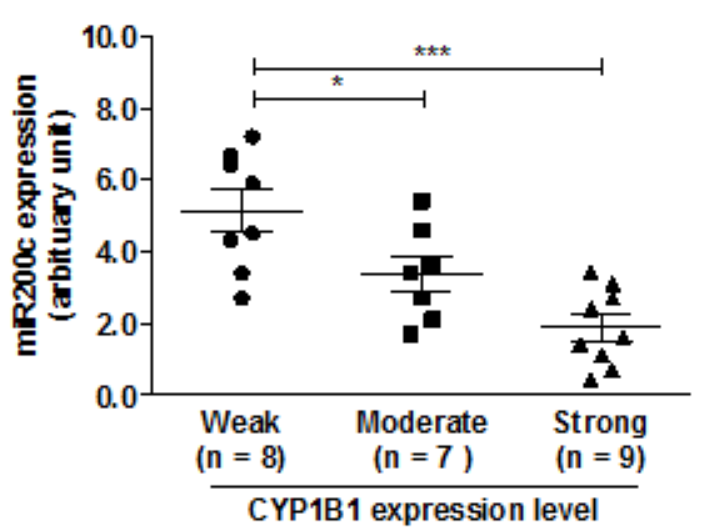

E

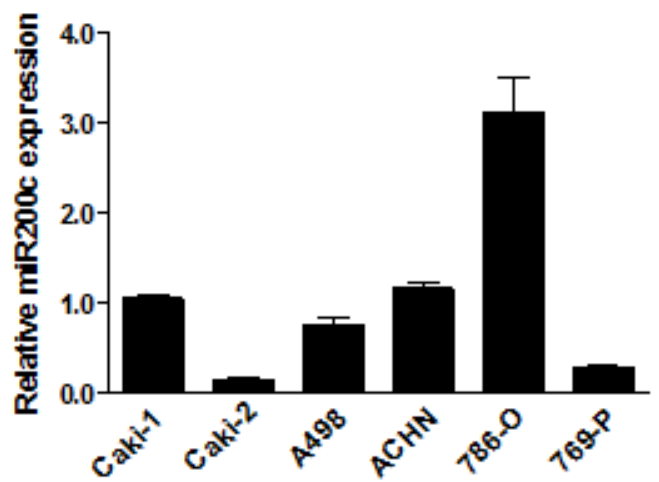

Figure 4: Inverse correlation between endogenous miR-200c level and CYP1B1 protein expression. (A) MiR-200c expression in RCC tissues. MiR-200c levels were analyzed by RT-PCR with RNA from microdissected tumor (T) and adjacent normal (N) tissues. (B) Summary of miR-200c expression levels in RCC tissue samples. (C) In situ hybridization of miR-200c expression in normal and RCC tissues. (D) Association of CYP1B1 expression with miR-200c levels in RCC tissues. MiR-200c levels were measured by RTPCR with RNA extracted from different scored and microdissected RCC tissue samples. $* P<0.05$; $* * * P<0.001$ (E) Relative miR-200c expression in RCC cells was analyzed by RT-PCR. 
A

C

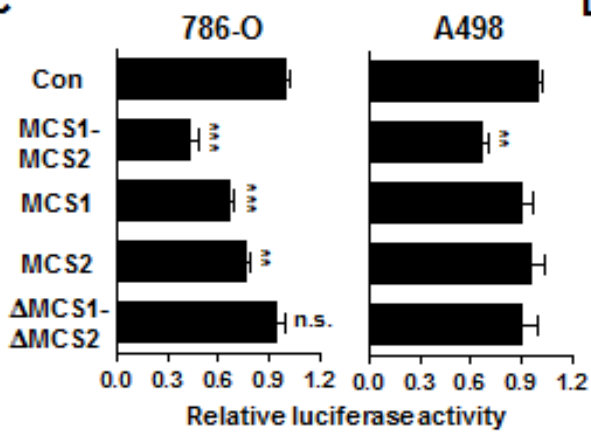

E

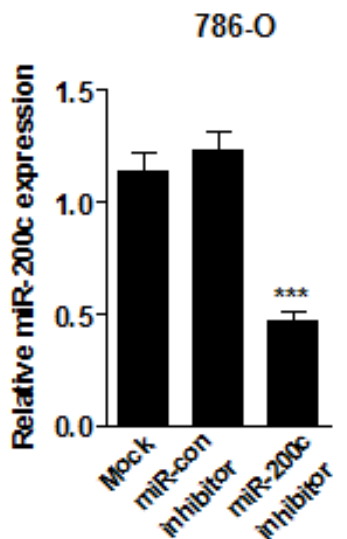

H

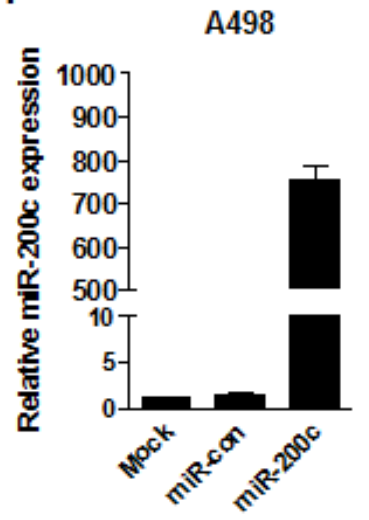

I
B

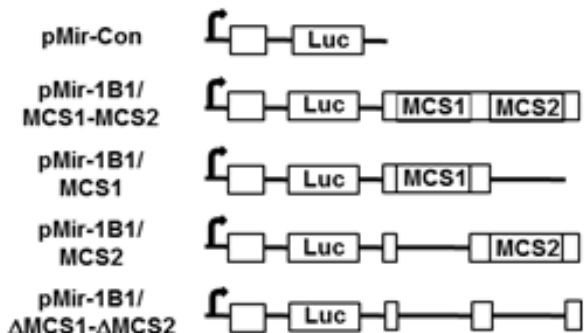

D
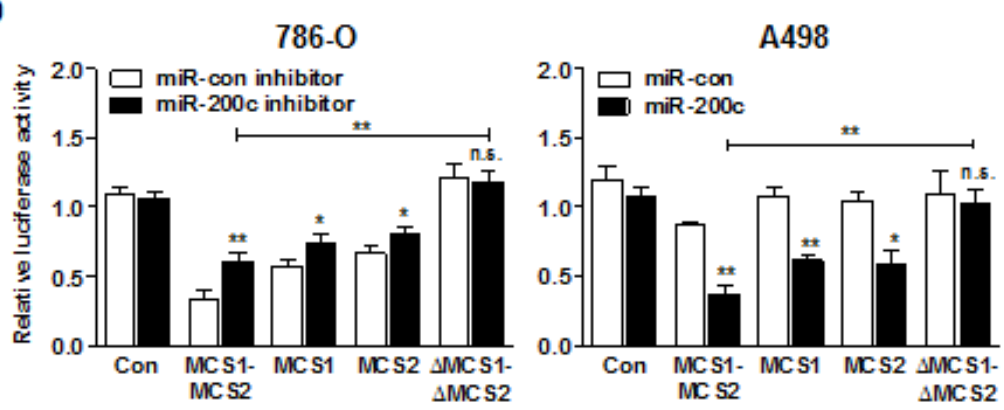

G

786-0

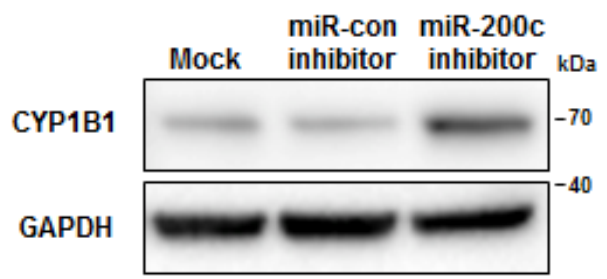

A498

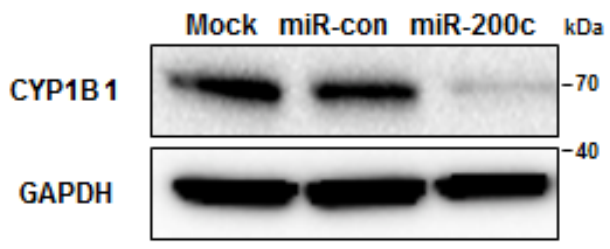

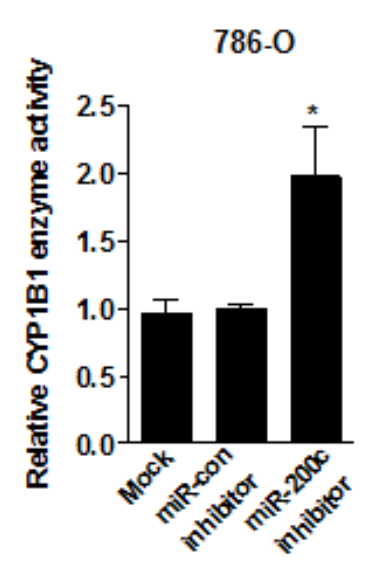

J

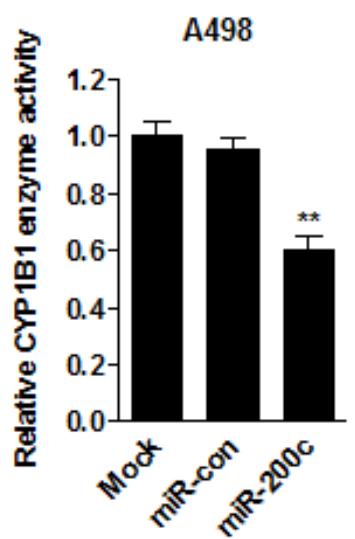

Figure 5: MiR-200c directly targets the CYP1B1 3'-UTR. (A) Sequence and location of MCS1 and 2 in the 3'-UTR of human CYP1B1 mRNA. (B) Diagram of reporter constructs containing the wild type or MCS-deleted 3'-UTR of human CYP1B1. (C) Relative luciferase activity after transfection of reporter constructs containing the wild type or MCS-deleted 3'-UTR of CYP1B1. ${ }^{* *} P<0.01$; $* * * P<0.001$; n.s.: non-significant (D) Relative luciferase activity after co-transfection of reporter constructs containing the wild type or MCS-deleted 3'-UTR of CYP1B1 with either miR-200c inhibitor or precursor. ${ }^{*} P<0.05$; $* * P<0.01$; n.s.: non-significant (E-G) After miR200c inhibitor transfection, relative miR-200c expression was analyzed by RT-PCR (E), CYP1B1 protein level was determined by Western blot (F) and enzyme activity was measured with P450-Glo assay (G) in 786-O cells. ${ }^{*} P<0.05$; ${ }^{*} * *<0.001$ (H-J) After miR-200c precursor transfection, relative miR-200c expression was analyzed by RT-PCR (H), CYP1B1 protein level was determined by Western blot (I) and enzyme activity was measured with P450-Glo assay (J) in A498 cells. $* * P<0.01$ 
the luciferase activities of the pMir-1B1/MCS1-MCS2 but not that of pMir-1B1/ $\mathrm{MCS} 1-\triangle \mathrm{MCS} 2$. These results suggest that miR-200c directly targets the MCS on the CYP1B1 3'-UTR and regulates its expression.

Next, we examined the effect of miR-200c on CYP1B1 protein levels and its enzymatic activity. In 786O cells, endogenous miR-200c levels were decreased by the miR-200c inhibitor (Fig. 5E). As shown in Fig. 5F and $\mathrm{G}$, the CYP1B1 protein level and enzyme activity were significantly increased by the miR-200c inhibition. In reciprocal experiments, we also looked the effects of miR200c overexpression in A498 cells. MiR-200c expression was greatly increased by the transfection of its precursor in A498 cells (Fig. 5H). Conversely, CYP1B1 protein and enzyme activity were significantly decreased by miR-200c overexpression (Fig. 5I and J). These results suggest that miR-200c represses CYP1B1 mRNA expression resulting in the reduction of CYP1B1 protein level and enzymatic activity.

\section{MiR-200c-mediated CYP1B1 regulation affects the resistance of $\mathrm{RCC}$ cells to docetaxel}

To determine whether miR-200c affects RCC chemosensitivity, the cytotoxic effect of docetaxel was measured after miR-200c restoration or inhibition. A significant increase in the cytotoxic effect of docetaxel was observed and as a consequence, the cell survival rate was reduced by transfection of $\mathrm{miR}-200 \mathrm{c}$ precursor in A498 cells (Fig. 6A and B). MiR-200c inhibition significantly decreased the cytotoxic effect of docetaxel and enhanced the survival rate of 786-O cells (Fig. 6C and D). To verify the effects of miR-200c via CYP1B1 on the chemosensitivity to docetaxel, we introduced CYP1B1 plasmid into A498 cells after miR-200c overexpression and examined cytotoxicity. Restoration of CYP1B1 protein levels was verified after transfection (Fig. 6E). We observed that the increase in the cytotoxic effect of docetaxel by miR-200c overexpression was reversed by the enforced CYP1B1 expression (Fig. 6F). As a consequence, cell survival was also restored by the exogenous CYP1B1expression (Fig. 6G). These results indicate that CYP1B1 regulation by miR-200c directly influences the chemosensitivity of RCC cells to docetaxel.

\section{DISCUSSION}

It has been suggested that CYP1B1 may be important in tumor development and progression, and also contributes to drug resistance [31,32]. Saini et al. showed that CYP1B1 up-regulation plays an essential role in endometrial carcinogenesis [14]. In head and neck carcinogenesis, CYP1B1 knockdown reduced the migration and proliferation of premalignant cells [15]. Based on these studies, we examined the functional role of CYP1B1 in RCC using siRNA-mediated CYP1B1 knockdown. Unlike other studies, CYP1B1 deficiency had no influence on RCC tumorigenicity. Interestingly, we found that CYP1B1 is involved in the docetaxel resistance of RCC cells. CYP1B1 overexpression in $\mathrm{V} 79$ cells reduced the in vitro cytotoxicity of docetaxel and this effect was reversed in the presence of CYP1B1 inhibitor [11]. Although it is controversial [33, 34], one of the CYP1B1 polymorphic variants, Leu432Val, which may increase enzymatic activity, is associated with low response to taxane in breast cancer [12] and poor prognosis in docetaxel-treated prostate cancer patients $[13,35]$. The L432V allelic variants were also associated with reduced sensitivity to DNA-interacting agents, alkylators, camptothecins, topoisomerase II inhibitors, and antimetabolites [36]. Our previous study suggests that CYP1B1 gene polymorphisms are risk factors for RCC [37]. Therefore, it would be of interest to determine whether the CYP1B1 polymorphic variants, especially the L432V allelic variant, are related to the resistance of RCC to chemotherapeutics.

Several hypotheses have been proposed to explain how CYP1B1 decreases the cytotoxic effect of docetaxel. Rochat et al. initially suggested that docetaxel is metabolized by CYP1B1 [32]. However, other studies were unable to detect catalytic activity and effect of CYP1B1 during the metabolism and clearance of docetaxel, respectively $[13,38]$. Sissung et al. showed that both $2-\mathrm{OHE}_{2}$ and $4-\mathrm{OHE}_{2}$, the catechol estrogen metabolites of CYP1B1 hamper the docetaxel-mediated tubulin polymerization. They also presumed that the covalent binding of CYP1B1-catalyzed E2-3, 4-quinone to docetaxel may reduce the cytotoxic potency of the drug [13]. CYP1B1 expression or its metabolites may also trigger an intracellular protective signaling pathway against docetaxel cytotoxicity. Martinez et al. showed that docetaxel induces CYP1B1 expression and drug resistance in breast but not in lung, colon, or pancreatic cancer cells. They also suggested that docetaxel resistance is not due to the direct inactivation of docetaxel by CYP1B1 but rather the indirect mechanism of promoting cancer cell survival based on the pro-apoptotic effect of CYP1B1 knockdown in endometrial cancer cells [39]. However, in RCC cells, CYP1B1 reduction does not affect tumorigenicity and no docetaxel-mediated CYP1B1induction was observed (Supplementary Fig. S1 and S4). Therefore, it may be possible that CYP1B1 is involved in docetaxel resistance through diverse mechanisms in each different type of cancer. MiR-200c is an important regulator of EMT, which has been suggested as one of the regulatory mechanisms of drug resistance [40]. According to our study, CYP1B1 is an essential target of miR-200c-mediated docetaxel resistance. Thus, further studies are needed to determine whether CYP1B1 is involved in EMT.

CYP1B1 has been considered to be a promising prognostic and diagnostic marker for $\mathrm{RCC}$, however 
no studies have been conducted to document it so far. In this study, we examined the association between CYP1B1 expression and RCC clinicopathologic factors. However, no correlation was observed between CYP1B1 expression and RCC tumor type, stage, grade, and 5-year survival probability after surgery. Importantly, we observed that CYP1B1 expression is associated with the chemosensitivity of RCC cells to docetaxel. Although our sample number is small, it was enough to obtain statistical significance. A larger sample size might be needed to draw a more concrete conclusion about the association between CYP1B1 expression and clinical indicators of RCCs. In addition, it will be helpful to perform studies on the association of CYP1B1 expression and its polymorphic variants with the efficiency of docetaxel treatment in RCC patients to confirm this study.

Several reports have indicated that miR-200c is down-regulated in RCC tissues [19-21]. However, little is known about the functional significance of low miR200c expression in RCC. Reduced miR-200c level is associated with aggressiveness and chemoresistance in female reproductive cancers and its restoration enhances sensitivity to paclitaxel by targeting class III beta tubulin [41, 42]. In addition, miR-200c is associated with cisplatin and doxorubicin sensitivity through regulation of Akt, AP-2 $\alpha$, TrkB and Bmil [24, 25, 43]. In this
A

A498

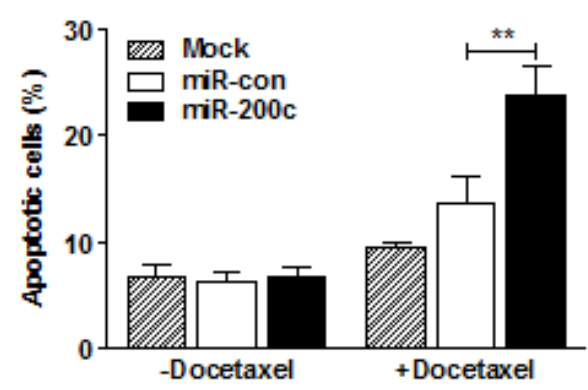

C

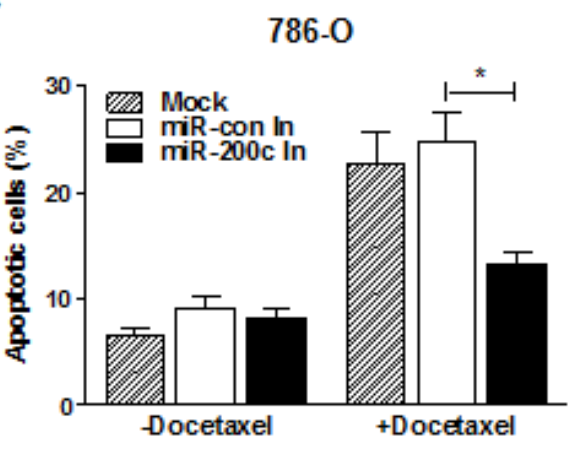

E

A498

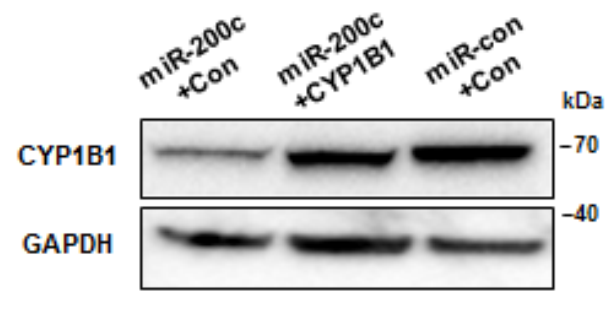

B

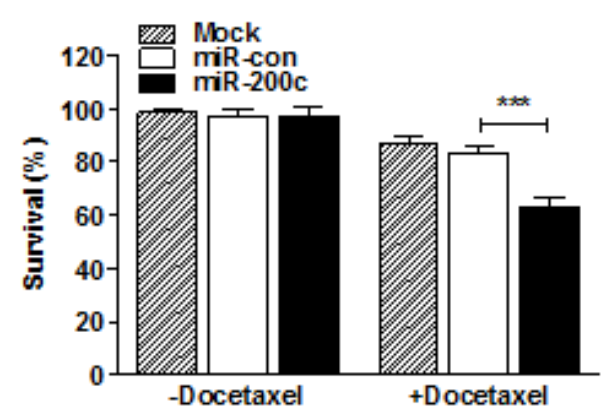

D

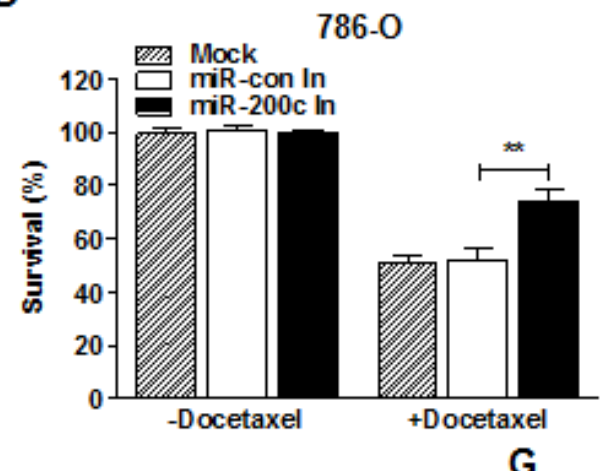

$\mathbf{F}$

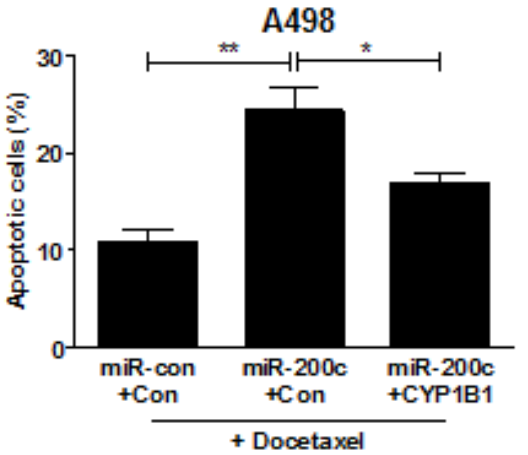

G

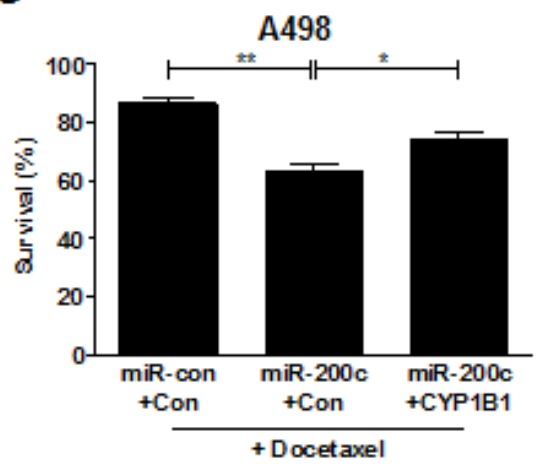

Figure 6: MiR-200c regulates docetaxel resistance of RCC cells. (A and B) After miR-200c precursor transfection, A498 cells were treated with docetaxel $(5 \mu \mathrm{M})$ for $72 \mathrm{hrs}$. Apoptotic cell death was measured with annexin V-FITC/7-AAD staining (A) and cell survival was analyzed by MTS assay (B). ${ }^{* *} P<0.01$; ${ }^{* * *} P<0.001$ (C and D) After miR-200c inhibitor transfection, 786-O cells were treated with docetaxel $(5 \mu \mathrm{M})$ for $72 \mathrm{hrs}$. Apoptotic cell death was measured with annexin V-FITC/7-AAD staining (C) and cell survival was analyzed by MTS assay (D). ${ }^{*} P<0.05$; ${ }^{*} P<0.01$ (E-G) After transfection of miR-200c precursor with either control or CYP1B1 plasmid, A498 cells were treated with docetaxel $(5 \mu \mathrm{M})$ for $72 \mathrm{hrs}$. CYP1B1 protein expression was determined by Western blot (E), apoptotic cell death was measured with annexin V-FITC/7-AAD staining (F) and cell survival was analyzed by MTS assay $(\mathrm{G}) .{ }^{*} P<0.05$; $* * P<0.01$ 
study, we identified CYP1B1 to be an effector for miR200c-mediated regulation of RCC chemosensitivity to docetaxel. Therefore, it would be of interest to examine whether genes known to be related with drug resistance such as ATP-binding cassette transporters and major vault protein are also regulated by miR-200c. According to Tsuchiya et al., lack of miR-27b which inhibits the translation of CYP1B1 mRNA into protein in normal but not cancer cells causes up-regulation of CYP1B1 protein level in breast cancer cells [7]. Therefore, it would be of great interest to determine whether miR-27b-mediated CYP1B1 regulation is involved in docetaxel resistance in both breast and kidney cancers. The information obtained by these types of studies will provide additional insight into understanding the significance of miRNAs in RCC drug resistance.

In conclusion, the present findings indicate that CYP1B1 is post-transcriptionally regulated by miR$200 \mathrm{c}$ and thus, high CYP1B1 protein expression and enzyme activity may be caused by low expression of miR-200c in RCC. CYP1B1 up-regulation is not related to tumorigenicity and is unlikely to be associated with RCC clinicopathological parameters. Interestingly, our study found that miR-200c-mediated CYP1B1 regulation is involved in the chemosensitiviy of RCC to docetaxel. These results indicate that CYP1B1 and miR-200c may be useful as potential biomarkers for chemotherapy and therefore, help to provide more options for RCC treatment.

\section{MATERIALS AND METHODS}

\section{Cell lines and reagents}

The renal cancer cell lines, Caki-1, Caki-2, A498, $\mathrm{ACHN}, 786-\mathrm{O}$ and 769-P were obtained from the American Type Culture Collection. McCoy's 5A, MEM Eagle's with Earle's BSS (EMEM), RPMI 1640, OptiMEM and penicillin/streptomycin mixtures were obtained from the UCSF Cell Culture Facility. Fetal bovine serum (FBS) was a product of Atlanta Biologicals. Docetaxel was purchased from Sigma Chemical Co.

\section{Cell culture}

Caki-1 and Caki-2 cells were grown in McCoy's 5A, and A498 and ACHN cells were maintained in EMEM medium while 786-O and 769-P cells were cultured in RPMI 1640 medium. All culture medium contained 10\% FBS and $100 \mu \mathrm{g} / \mathrm{ml}$ penicillin/streptomycin. All cell lines were maintained at $37^{\circ} \mathrm{C}$ in a humidified atmosphere composed of $5 \% \mathrm{CO}_{2} / 95 \%$ air.

\section{Cell viability assay}

For chemosensitivity assay, cells were seeded in triplicate in 96-well plates at a density of $250-1,000$ cells/ well as appropriate and grown for $24 \mathrm{~h}$ and then treated with docetaxel at 10 serially diluted concentrations between 0.05 and $100 \mu \mathrm{M}$ for $72 \mathrm{~h}$. For cell survival assay, cells were plated in triplicate in 96-well plates at a density of 5,000 cells/well and then treated with docetaxel. In some cases, miR-200c precursor, inhibitor, CYP1B1 plasmid or siRNAs along with their controls were transfected before treatment. At the desired time point, the number of viable cells was determined by adding 3-(4,5-dimethylthiazol2-yl)-5-(3-carboxymethoxyphenyl)-2-(4-sulfophenyl)2H-tetrazolium (MTS)-based CellTiter $96 \mathrm{AQ}_{\text {uеous }}$ One Solution Reagent (Promega) to each well and measuring the absorbance at $490 \mathrm{~nm}$ on a SPECTRA MAX 190 plate reader (Molecular Devices). Results were expressed as percentage of optical density, assuming that the absorbance of control cells was $100 \%$.

\section{Western blot analysis}

Whole cell extracts were prepared using radioimmunoprecipitation assay buffer (Thermo Scientific) containing protease inhibitor cocktails (Roche). Antibodies against CYP1B1 (Abcam) and glyceraldehyde3-phosphate dehydrogenase (GAPDH; Santa Cruz Biotechnology) were used to detect protein expression.

\section{Colony formation assay}

Cells were seeded at 1,000 cells/plate and treated with doxetacel. After 14 days incubation, the colony were fixed with glutaraldehyde $(6.0 \% \mathrm{v} / \mathrm{v})$, stained with crystal violet $(0.5 \% \mathrm{w} / \mathrm{v})$ and counted with a microscope.

\section{Apoptosis assay}

Apoptosis was analyzed with an annexin V-fluorescein isothiocyanate (FITC)/7-amino-actinomycin $\mathrm{D}$ (7-AAD) staining system (BD Biosciences) and a Cell Lab Quanta ${ }^{\mathrm{TM}}$ SC MPL (Beckman Coulter). Cells were stained with annexin V-FITC only (early apoptotic) or both annexin V-FITC and 7-AAD (late apoptotic) were considered as the apoptotic cell fractions.

\section{CYP1B1 enzymatic activity}

CYP1B1 enzymatic activity was determined using a P450-Glo Assay kit (Promega) according to the manufacturer's instructions. The enzymatic activity was normalized to the protein content. 


\section{Transfection}

For CYP1B1 overexpression, cells were transfected with pCMV6-ENTRY vector expressing human CYP1B1 cDNA or empty pCMV6-ENTRY vector (OriGene Technologies) using Fugene HD Transfection Reagent (Roche Diagnostics) according to the manufacturer's protocol. For CYP1B1 knockdown, cells were transfected with $10 \mathrm{nM}$ CYP1B1 siRNAs or universal scrambled negative control (OriGene Technologies). For miR-200c inhibition, cells were transfected with $20 \mathrm{nM}$ Anti-miR miRNA Inhibitor for has-miR-200c or Anti-miR miRNA Inhibitor Negative Control (Ambion). For miR-200c overexpression, cells were transfected with $50 \mathrm{nM}$ PremiR miRNA Precursor of has-miR-200c or Pre-miR miRNA Negative Control (Ambion). Lipofectamine ${ }^{\mathrm{TM}}$ 2000 Tansfection Reagent (Invitrogen) was used for the transfection of CYP1B1 siRNA, miRNA precursor and inhibitor as described by the manufacturer's instructions. Cells treated with Lipofectamine ${ }^{\mathrm{TM}} 2000$ Transfection Reagent alone were included as a mock control for each experiment.

\section{Quantitative RT-PCR}

Total RNA was extracted from microdissected formalin-fixed, paraffin-embedded (FFPE) tissues and cultured cells using miRNeasy Mini Kit or RNeasy Mini Kit (Qiagen) and was converted into cDNA by using TaqMan MicroRNA Reverse Transcription Kit (Applied Biosystems) or iScript $^{\mathrm{TM}}$ cDNA Synthesis Kit (BIORAD) according to the manufacturer's instruction. To assess gene expression, cDNAs were amplified with the TaqMan ${ }^{\circledR}$ Gene Expression Assays and TaqMan ${ }^{\circledR}$ Fast Universal PCR Master Mix using the 7500 Fast RealTime PCR System. The target genes and their Assay ID were as follows: CYP1B1 (Hs0016383_m1), GAPDH (Hs03929097_g1), miR-200c (002300) and RNU48 (001006). The relative level was calculated by the comparative $C_{\mathrm{t}}$ method $\left(\Delta \Delta C_{\mathrm{t}}\right)$ using the 7500 Fast System Sequence Detection Software (Applied Biosystems).

\section{RCC tissue samples}

Tissue samples of radical nephrectomy were obtained from the patients enrolled in the San Francisco Veterans Affairs Medical Center (SFVAMC). Informed consent was obtained from all patients. All slides were reviewed by a board-certified pathologist for the identification of tumor foci and normal adjacent tissue. For microdissections, $10 \mu \mathrm{m}$-unstained sections were microdissected with an Autopix Laser Capture Microdissection System (Molecular Devices) using $4 \mu \mathrm{m}$ sections stained with hematoxylin and eosin and marked tumor and normal adjacent areas as a template.

\section{Reporter assay}

CYP1B1 3'UTR luciferase reporter clone was obtained from Origene Technologies along with control construct (pMirTarget). For miR-200c complementary sequence (MCS) mutants, deletion mutagenesis was conducted by overlap extension PCR [44]. The primer sequences are as follows: F1, 5'-AAAGAATTCACAAGCCAAGGAAACTTGCCA-3'; F2, 5'-CTGAATGAATTGGTAACCAGGCCATTT-3'; F3, 5'-AAAAATCATTTTAAAGGCATTAGAGTC-3'; R1, 5'-GGTTACCAATTCATTCAGTAGTTTGGT-3'; R2, 5'-GCCTTTAAAATGATTTTTTATATTCAA-3'; R3, 5'-AAAGCGGCCGCTTGGTAATGGTGTC CCAGTAT-3'. After transfection, luciferase activity was measured with a PerkinElmer 2030 Multilabel reader (PerkinElmer) using the Dual-Glo Luciferase Assay System (Promega).

\section{Immunohistochemistry}

Immunostaining was performed on FFPE RCC sections using the VECTASTAIN ABC Kit (Vector Laboratories) according to the manufacturer's instructions. After incubation with anti-CYP1B1 antibody (Abcam), ImmPACT DAB (Vector Laboratories) was added as chromogen followed by counterstaining with hematoxylin. Staining intensity of each tissue section was visually evaluated with an Olympus BX60 microscope equipped with Spot Advanced software (Diagnostic Instruments) and was ranked on an overall scale from 0 to 3 ; with 0 indicating the absence of staining; 1, weak staining; 2 , moderate staining; and 3 , strong staining.

\section{In situ hybridization}

In situ hybridization (ISH) was performed on FFPE RCC sections using the digoxigenin (DIG)-labeled miRCURY Locked Nucleic Acid (LNA) microRNA Detection probes for miR-200c and U6 (Exiqon) following the manufacturer's protocol. Hybridization was performed overnight at $57{ }^{\circ} \mathrm{C}$ and detected with horseradish peroxidase-conjugated anti-DIG antibody (Abcam). Abundance of target RNA was detected using ImmPACT DAB peroxidase substrate (Vector Laboratories).

\section{Statistical analysis}

Values are presented as the mean \pm standard error of mean (SEM) based on results obtained from at least three independent experiments. All statistical analyses were carried out using GraphPad PRISM Software. Two- 
tailed unpaired Student's $t$-test was used for comparisons between two groups. Chi-square test was used for analyzing the correlation between clinicopathologic parameters and CYP1B1 protein expression. Significance of percent survival after surgery was done with logrank test. The difference of miR-200c expression was determined by Mann-Whitney $U$ test. The relationship between the levels of CYP1B1 protein and miR-200c was investigated by ANOVA and Tukey method test. A $P$ value of $<0.05$ was regarded as statistically significant.

\section{ACKNOWLEDGEMENTS}

We thank Dr. Roger Erickson for helpful discussion and comments about the manuscript.

\section{REFERENCES}

1. Jemal A, Siegel R, Ward E, Hao Y, Xu J, Murray T and Thun MJ. Cancer statistics, 2008. CA Cancer J Clin. 2008; 58(2):71-96.

2. De Mulder PH, van Herpen CM and Mulders PA. Current treatment of renal cell carcinoma. Ann Oncol. 2004; 15 Suppl 4:iv319-328.

3. Murray GI. The role of cytochrome P450 in tumour development and progression and its potential in therapy. $\mathrm{J}$ Pathol. 2000; 192(4):419-426.

4. Sutter TR, Tang YM, Hayes CL, Wo YY, Jabs EW, Li $\mathrm{X}$, Yin H, Cody CW and Greenlee WF. Complete cDNA sequence of a human dioxin-inducible mRNA identifies a new gene subfamily of cytochrome P450 that maps to chromosome 2. J Biol Chem. 1994; 269(18):13092-13099.

5. Sissung TM, Price DK, Sparreboom A and Figg WD. Pharmacogenetics and regulation of human cytochrome P450 1B1: implications in hormone-mediated tumor metabolism and a novel target for therapeutic intervention. Mol Cancer Res. 2006; 4(3):135-150.

6. Murray GI, Taylor MC, McFadyen MC, McKay JA, Greenlee WF, Burke MD and Melvin WT. Tumor-specific expression of cytochrome P450 CYP1B1. Cancer Res. 1997; 57(14):3026-3031.

7. Tsuchiya Y, Nakajima M, Takagi S, Taniya T and Yokoi T. MicroRNA regulates the expression of human cytochrome P450 1B1. Cancer Res. 2006; 66(18):9090-9098.

8. Bandiera S, Weidlich S, Harth V, Broede P, Ko Y and Friedberg T. Proteasomal degradation of human CYP1B1: effect of the Asn453Ser polymorphism on the posttranslational regulation of CYP1B1 expression. Mol Pharmacol. 2005; 67(2):435-443.

9. Hayes CL, Spink DC, Spink BC, Cao JQ, Walker NJ and Sutter TR. 17 beta-estradiol hydroxylation catalyzed by human cytochrome P450 1B1. Proc Natl Acad Sci U S A. 1996; 93(18):9776-9781.

10. Zhang Y, Gaikwad NW, Olson K, Zahid M, Cavalieri
EL and Rogan EG. Cytochrome P450 isoforms catalyze formation of catechol estrogen quinones that react with DNA. Metabolism. 2007; 56(7):887-894.

11. McFadyen MC, McLeod HL, Jackson FC, Melvin WT, Doehmer J and Murray GI. Cytochrome P450 CYP1B1 protein expression: a novel mechanism of anticancer drug resistance. Biochem Pharmacol. 2001; 62(2):207-212.

12. Rizzo R, Spaggiari F, Indelli M, Lelli G, Baricordi OR, Rimessi P and Ferlini A. Association of CYP1B1 with hypersensitivity induced by taxane therapy in breast cancer patients. Breast Cancer Res Treat. 2010; 124(2):593-598.

13. Sissung TM, Danesi R, Price DK, Steinberg SM, de Wit R, Zahid M, Gaikwad N, Cavalieri E, Dahut WL, Sackett DL, Figg WD and Sparreboom A. Association of the CYP1B1*3 allele with survival in patients with prostate cancer receiving docetaxel. Mol Cancer Ther. 2008; 7(1):19-26.

14. Saini S, Hirata H, Majid S and Dahiya R. Functional significance of cytochrome P450 1B1 in endometrial carcinogenesis. Cancer Res. 2009; 69(17):7038-7045.

15. Shatalova EG, Klein-Szanto AJ, Devarajan K, Cukierman E and Clapper ML. Estrogen and cytochrome P450 1B1 contribute to both early- and late-stage head and neck carcinogenesis. Cancer Prev Res (Phila). 2011; 4(1):107115.

16. Bartel DP. MicroRNAs: target recognition and regulatory functions. Cell. 2009; 136(2):215-233.

17. Schickel R, Boyerinas B, Park SM and Peter ME. MicroRNAs: key players in the immune system, differentiation, tumorigenesis and cell death. Oncogene. 2008; 27(45):5959-5974.

18. Park SM, Gaur AB, Lengyel E and Peter ME. The miR-200 family determines the epithelial phenotype of cancer cells by targeting the E-cadherin repressors ZEB1 and ZEB2. Genes Dev. 2008; 22(7):894-907.

19. Nakada C, Matsuura K, Tsukamoto Y, Tanigawa M, Yoshimoto T, Narimatsu T, Nguyen LT, Hijiya N, Uchida T, Sato F, Mimata H, Seto M and Moriyama M. Genome-wide microRNA expression profiling in renal cell carcinoma: significant down-regulation of miR-141 and miR-200c. J Pathol. 2008; 216(4):418-427.

20. White NM, Bao TT, Grigull J, Youssef YM, Girgis A, Diamandis M, Fatoohi E, Metias M, Honey RJ, Stewart R, Pace KT, Bjarnason GA and Yousef GM. miRNA profiling for clear cell renal cell carcinoma: biomarker discovery and identification of potential controls and consequences of miRNA dysregulation. J Urol. 2011; 186(3):1077-1083.

21. Liu H, Brannon AR, Reddy AR, Alexe G, Seiler MW, Arreola A, Oza JH, Yao M, Juan D, Liou LS, Ganesan S, Levine AJ, Rathmell WK and Bhanot GV. Identifying mRNA targets of microRNA dysregulated in cancer: with application to clear cell Renal Cell Carcinoma. BMC Syst Biol. 2010; 4:51.

22. Adam L, Zhong M, Choi W, Qi W, Nicoloso M, Arora A, Calin G, Wang H, Siefker-Radtke A, McConkey D, Bar-Eli 
M and Dinney C. miR-200 expression regulates epithelialto-mesenchymal transition in bladder cancer cells and reverses resistance to epidermal growth factor receptor therapy. Clin Cancer Res. 2009; 15(16):5060-5072.

23. Ceppi P, Mudduluru G, Kumarswamy R, Rapa I, Scagliotti GV, Papotti M and Allgayer H. Loss of miR$200 \mathrm{c}$ expression induces an aggressive, invasive, and chemoresistant phenotype in non-small cell lung cancer. Mol Cancer Res. 2010; 8(9):1207-1216.

24. Hamano R, Miyata H, Yamasaki M, Kurokawa Y, Hara J, Moon JH, Nakajima K, Takiguchi S, Fujiwara Y, Mori $\mathrm{M}$ and Doki Y. Overexpression of miR-200c induces chemoresistance in esophageal cancers mediated through activation of the Akt signaling pathway. Clin Cancer Res. 2011; 17(9):3029-3038.

25. Kopp F, Oak PS, Wagner E and Roidl A. miR-200c sensitizes breast cancer cells to doxorubicin treatment by decreasing TrkB and Bmil expression. PLoS One. 2012; 7(11):e50469.

26. Cittelly DM, Dimitrova I, Howe EN, Cochrane DR, Jean A, Spoelstra NS, Post MD, Lu X, Broaddus RR, Spillman MA and Richer JK. Restoration of miR-200c to ovarian cancer reduces tumor burden and increases sensitivity to paclitaxel. Mol Cancer Ther. 2012; 11(12):2556-2565.

27. Rahman A, Korzekwa KR, Grogan J, Gonzalez FJ and Harris JW. Selective biotransformation of taxol to 6 alphahydroxytaxol by human cytochrome P450 2C8. Cancer Res. 1994; 54(21):5543-5546.

28. Marre F, Sanderink GJ, de Sousa G, Gaillard C, Martinet $\mathrm{M}$ and Rahmani R. Hepatic biotransformation of docetaxel (Taxotere) in vitro: involvement of the CYP3A subfamily in humans. Cancer Res. 1996; 56(6):1296-1302.

29. Sparreboom A, van Asperen J, Mayer U, Schinkel AH, Smit JW, Meijer DK, Borst P, Nooijen WJ, Beijnen JH and van Tellingen $\mathrm{O}$. Limited oral bioavailability and active epithelial excretion of paclitaxel (Taxol) caused by P-glycoprotein in the intestine. Proc Natl Acad Sci U S A. 1997; 94(5):2031-2035.

30. McFadyen MC, Melvin WT and Murray GI. Cytochrome P450 CYP1B1 activity in renal cell carcinoma. Br J Cancer. 2004; 91(5):966-971.

31. Shimada T, Hayes CL, Yamazaki H, Amin S, Hecht SS, Guengerich FP and Sutter TR. Activation of chemically diverse procarcinogens by human cytochrome P-450 1B1. Cancer Res. 1996; 56(13):2979-2984.

32. Rochat B, Morsman JM, Murray GI, Figg WD and McLeod HL. Human CYP1B1 and anticancer agent metabolism: mechanism for tumor-specific drug inactivation? J Pharmacol Exp Ther. 2001; 296(2):537-541.

33. Gehrmann M, Schmidt M, Brase JC, Roos P and Hengstler JG. Prediction of paclitaxel resistance in breast cancer: is CYP1B1*3 a new factor of influence? Pharmacogenomics. 2008; 9(7):969-974.

34. Marsh S, Somlo G, Li X, Frankel P, King CR, Shannon
WD, McLeod HL and Synold TW. Pharmacogenetic analysis of paclitaxel transport and metabolism genes in breast cancer. Pharmacogenomics J. 2007; 7(5):362-365.

35. Pastina I, Giovannetti E, Chioni A, Sissung TM, Crea F, Orlandini C, Price DK, Cianci C, Figg WD, Ricci S and Danesi R. Cytochrome 450 1B1 (CYP1B1) polymorphisms associated with response to docetaxel in CastrationResistant Prostate Cancer (CRPC) patients. BMC Cancer. 2010; 10:511.

36. Laroche-Clary A, Le Morvan V, Yamori T and Robert J. Cytochrome P450 1B1 gene polymorphisms as predictors of anticancer drug activity: studies with in vitro models. Mol Cancer Ther. 2010; 9(12):3315-3321.

37. Sasaki M, Tanaka Y, Okino ST, Nomoto M, Yonezawa S, Nakagawa M, Fujimoto S, Sakuragi N and Dahiya R. Polymorphisms of the CYP1B1 gene as risk factors for human renal cell cancer. Clin Cancer Res. 2004; 10(6):2015-2019.

38. Bournique B and Lemarie A. Docetaxel (Taxotere) is not metabolized by recombinant human CYP1B1 in vitro, but acts as an effector of this isozyme. Drug Metab Dispos. 2002; 30(11):1149-1152.

39. Martinez VG, O'Connor R, Liang $\mathrm{Y}$ and Clynes M. CYP1B1 expression is induced by docetaxel: effect on cell viability and drug resistance. Br J Cancer. 2008; 98(3):564570 .

40. Wang Z, Li Y, Ahmad A, Azmi AS, Kong D, Banerjee $\mathrm{S}$ and Sarkar FH. Targeting miRNAs involved in cancer stem cell and EMT regulation: An emerging concept in overcoming drug resistance. Drug Resist Updat. 2010; 13(4-5):109-118.

41. Cochrane DR, Howe EN, Spoelstra NS and Richer JK. Loss of miR-200c: A Marker of Aggressiveness and Chemoresistance in Female Reproductive Cancers. J Oncol. 2010; 2010:821717.

42. Leskela S, Leandro-Garcia LJ, Mendiola M, Barriuso J, Inglada-Perez L, Munoz I, Martinez-Delgado B, Redondo A, de Santiago J, Robledo M, Hardisson D and RodriguezAntona C. The miR-200 family controls beta-tubulin III expression and is associated with paclitaxel-based treatment response and progression-free survival in ovarian cancer patients. Endocr Relat Cancer. 2011; 18(1):85-95.

43. Wu Y, Xiao Y, Ding X, Zhuo Y, Ren P, Zhou C and Zhou J. A miR-200b/200c/429-binding site polymorphism in the 3 ' untranslated region of the AP-2alpha gene is associated with cisplatin resistance. PLoS One. 2011; 6(12):e29043.

44. Lee J, Shin MK, Ryu DK, Kim S and Ryu WS. Insertion and deletion mutagenesis by overlap extension PCR. Methods Mol Biol. 2010; 634:137-146. 